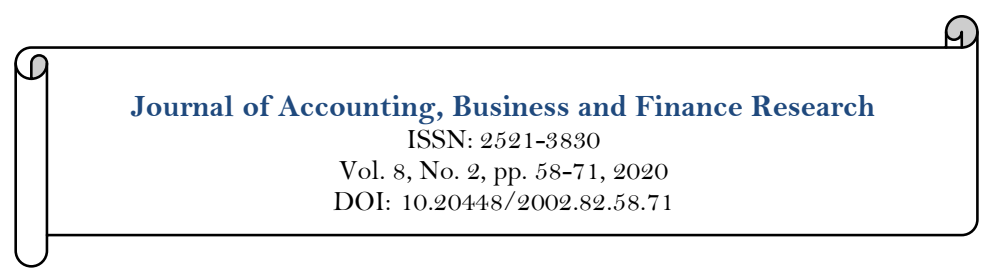
Updates

\title{
Performance Improvement of Non-Governmental Organisations through Financial Management: A Case study of Young Men's Christian Association of Ghana
}

\author{
Benedict Arthur ${ }^{2}$ \\ Richard Appiah-Kubi ${ }^{2}$
}

'School of Finance, Zhongnan University of Economics and Law, Wuhan, P.R. China. Email:arthurbenedict77@yahoo.com

${ }^{2}$ School of Management and Economics, Zhengzhou University, Zhenzhou, P.R. China.

\begin{tabular}{|c|c|}
\hline Abstract & \\
\hline $\begin{array}{l}\text { Non-governmental organizations (NGOS) in Ghana have a history of } \\
\text { being short-lived. However, Young Men's Christian Association (YMCA) } \\
\text { Ghana, on the other hand has achieved notable success by impacting millions } \\
\text { of lives over } 50 \text { years of working in Ghana. Apparently, this research } \\
\text { investigates into the key financial management practices of NGOs in Ghana } \\
\text { using the case of YMCA Ghana. The study revealed that, the quality of } \\
\text { Financial Management staff and their responsibility are the most effective } \\
\text { financial management indicator in YMCA Ghana amongst all the other } \\
\text { well-functioning indicators. Nevertheless, it is evident in the study that the } \\
\text { challenge YMCA Ghana faces in its financial management practice is } \\
\text { irregular external audit review offinancial and accounting data. Therefore, } \\
\text { it is recommended that frequent subscription for external audit services } \\
\text { should be established in NGOs and also, cost effective monitoring, } \\
\text { evaluation, accountability and learning (MEAL) programme management } \\
\text { framework should be adopted by NGOs in Ghana. }\end{array}$ & $\begin{array}{l}\text { Keywords: } \\
\text { Financial Management } \\
\text { Performance } \\
\text { NGOs } \\
\text { YMCA Ghana. } \\
\text { Licensed: } \\
\text { This work is licensed under a } \\
\text { Creative Commons Attribution } 4.0 \\
\text { License. } \\
\text { Publisher: } \\
\text { Scientific Publishing Institute } \\
\text { Accepted: } 8 \text { January } 2020 \\
\text { Published: } 22 \text { January } 2020\end{array}$ \\
\hline
\end{tabular}

Funding: The study did not have any funding support.

Competing Interests: The authors declare that they have no competing interests.

\section{Introduction}

The nonprofit sector has encountered phenomenal development in the course of recent decades, explicitly among associations that render human administrations. These organizations are rarely judged solely by their financial performance; instead, their worth is measured by the effectiveness of services rendered and how successful they are able to achieve their mission. And yet finances do matter. In many associations, the capacity to convey compelling administrations isn't just reliant on strong financing for those administrations, yet additionally on sound administration rehearses, of which financial management is an essential piece (Christine, William, \& Allen, 1999). Progressively, charitable associations, for example, NGOs are relied upon to utilize rare assets and accept financial substances into account as they settle on pragmatic decisions (Jerome, 2004).

Allis (2004) attests that financial resource is considered as a basic asset to pretty much every foundation and institution. In this manner, it must be successfully and proficiently figured out how to realize the required change and results from the action for which the assets have been made accessible. On the contrary, once in a while this significant asset is bungled and abused by those put in control (Rosen \& Gayer, 2010). Good management of an organization's finance offers quality fuel and normal assistance to guarantee productive working. In the event that accounts are not appropriately managed, an association will encounter difficulties that may have extreme consequences on its development and advancement. Financial Management is a is a principal managerial development in any affiliation. Financial management, as defined by is the way toward 
arranging, sorting out, controlling and checking money related assets with the goal of accomplishing authoritative objectives and expressed endpoints. The control of financial related activities of an association, for example, obtainment of assets, use of assets, bookkeeping, installments, hazard appraisal and every other thing related to money is an ideal practice. Financial management is highly indispensable for every successful organization, whether it's a private, government or non-government. Successful enterprises have the record of haven watched their finances very keenly and taking the right decisions at the right time hence the success of the organization. Most businesses have organized finance division responsible for looking after the accounts and finances of the company. In opposition to this, NGOs frequently don't believe financial management to be a precedence and thus, lack satisfactory financial knowledge. This is often characterized by poor financial planning and inadequate financial systems in place.

Non-governmental organizations (NGOs) have been broadly reprimanded for neglecting to change the lives of poor neighbourhoods in Ghana: the goal for which these affiliations were set up for. Pundits have differently ascribed the disappointment of most NGO exercises in the nation to issues of deficient financing support from outer sources, unseemly contributor control, rivalry among beneficiary/agents NGOs, and powerlessness to continue aggregate activity in recipient communities. Normally, endeavours attending to the challenge of NGOs terrible performance have frequently stressed a requirement for outer givers to build subsidizing support, lessen control over NGO activities, and ensure collaboration rather than competition among agent NGOs while overlooking at the poor management of the limited financial resources.

The significance and affectability of monetary management to an entity's mission for development has as of late brought the issue of fiscal governance and accountability to the lamplight of stakeholders (Zadek, 2003). This emphasis became even more pronounced in the wake of the collapse of world giants like Enron, Tyco and WorldCom among others and during the financial crisis of 2007-2009. Financial malfeasance is no news in the circles of Non-governmental organisations. Truth be told, aside from the centre issues that may evoke funding from such giver entities, another significant structure required by givers is an arrangement of good administration and responsibility of benefactor funds (Kihato \& Rapoo, 1999) which is commonly typified in a far reaching financial management framework. The failure of Enron, WorldCom and a large group of different organizations before and recent times has increased the interest for sound accountability rehearses on customary basis.

Financial control which is one of the effective internal control systems has become very important in modern business in the rise of fraudulent financial reporting across the world. Also, the quickly changing business condition of Not-revenue driven Organization is convincing corporate pioneers to guarantee sound and viable inside control framework to accomplish hierarchical targets. It is noted that the implementation of sound and effective financial management and controls will significantly ensure the achievement of objectives especially in the profit-making businesses because of the benefit augmenting intention. NGOs on the other hand had previously depended on traditional and informal procedures to sustain their social agenda of impacting lives. Unfortunately, taking a gander at the ongoing spate of financial malfeasance reported among NGOs, it shows up this isn't yielding the ideal outcomes.

Responsibility has been of significant test for NGOs. It was seen by Ayom (2013) that notwithstanding benefactors support, numerous NGOs are not performing admirably true to form. The Management Sciences for Health (MSH); a NGO in Sudan, couldn't represent \$17,788 proposed for weak individuals of South Sudan as a result of fraudulent exercises. A key insight was that the vast majority of donor assets to NGOs for venture execution needed accountability. Ayom (2013) referenced that a report directed by MSH between 2001-2013 demonstrated valid proof of false exercises especially expanded workshopcosts, manufactured receipts and deficient documentations. It was further reported that management ignore its responsibility and control measures were ineffectively executed within the organization.

Many NGOs in Ghana are faced with poor financial management practices which in extreme cases has led to the collapse of some of them, despite having the necessary resources and funds to run those (BoachieMensah \& Marfo-Yiadom, 2005). It is not weird to hear of NGOs funds being diverted to cater for other activities outside the scope and work plans of donors. For some, billing for non-existence events and inflating of invoices, inflation of operational costs, inflation of invoices produced internally for activities completed by own staff, billing for own contributions, and submission of forge receipts to cover expenditures are common forms of financial malpractices of NGOs in the region (Alhassan, Faustina, \& Evans, 2018). The situation has led to a number of NGOs inability to carry out their constructive work objectives and hence poor performance. The study, hence, endeavoured to inspect the tenacious poor performance of NGOs in Ghana from the point of view of monetary management which had until now been overlooked.

\section{Literature Review}

This section reviews related literature of the study that was written by other researchers. This was in respect to the variables and keywords of the study which are NGOs, Performance, and Financial Management from which specific objectives were framed for this research. 


\subsection{Overview of $N G O$ s in Ghana}

NGO is a non-benefit association that works autonomously of any administration, regularly one whose object is to address a social or political issue. The origin of NGOs in Ghana is dated back into time where through mutual assistance of the traditional Ghanaian idea of self-support under the "nnoboa" system led to the o the development of religious NGOs by the evangelists. The formation and development of NGOs in Ghana was moderate that as at 1930 just three of them had been formally enlisted. The quantity of NGOs expanded efficient during the 1960s and 1970s and by December 1996, more than 320 NGOs; both outside and indigenous were working in Ghana. It is very difficult to cite the total number of NGOs working in the nation on the grounds that the writing on NGOs in Ghana is insufficient. In any case, gauge number of NGOs both indigenous and foreign working in Ghana starting at 2005 was between $900-1500$ (ghanaweb.com). Currently, as of 2014, the number of registered NGOs from the statistics of the Department of Social Welfare database since registration started over two decades ago is five thousand nine hundred and eight (5298) and cumulating yearly.

The pre-independent era saw the rise of missionary activities that led in the establishment of religious groups mostly in rural communities (Amanor, Denkabe, \& Wellard, 1993; Atingdui, Anheier, \& Sokolowski, 1997; Grischow, 2008). With help from the colonial administration and minimal resistance from government, these groups setup their own hospitals; schools and other institutions to assist rural communities within the country for their welfare (Atingdui et al., 1997). Katsriku and Oquaye (1996) asserts that the pre-independent era of Ghana also saw the formation of foreign NGOs such as the Red Cross Society and the Society for the Prevention of Tuberculosis to help the vulnerable people in urban cities in Ghana. The formation of NGOs further intensified after the Second World Ward due to the desire and determination of the inhabitants to obtain independence from colonial rule and to resist racial discrimination (Mohan, 2002). It is further argued that NGOs were very instrumental in the struggle for independence (Abdul-Gafaru \& Quantson, 2008). The activities of these foreign NGOs were extended to rural areas of the country during post-independence.

In this current day modern Ghana, there are two main processes for registration as an NGO in Ghana: Firstly, NGOs are expected to get a certificate to commence business from the Registrar General's Department under the Ministry of Justice and Attorney General. Secondly, register as a local or international NGO at the Department of Social Welfare under the Ministry of Employment and Social Welfare. Similarly, in the modus operandi for NGOs in Ghana, an NGO is required to restore its enrolment consistently. Failure to renew amounts to termination of operations and will lead to the declaration of the organization as nonentity/invalid.

NGOs in Ghana are heterogeneous actors, they contrast in exercises, structure, association, assets, authority, enrolment, belief system and desire yet they all possess some level of financial resources that need to be effectively managed to achieve their various objectives for which the organizations were established. NGOs in Ghana exist to provide services to mostly deprived communities in areas such as education, sanitation, health, research and development, water development, agriculture, environmental protection, vocational skills, food security, capacity building and poverty reduction programmes such as micro-credit (Porter, 2003). NGOs in Ghana might be national just as global; mainstream just as religious; and participation or non-participation based.

\subsection{Financial Management of Not-for-Profit (NGOs)}

McMenamin (1999) describes fiscal management as 'the methods of overseeing cash'. Financial management is technically considered as the determination, acquisition, allocation, and utilization of financial resource, with the objective of achieving precise set goals or objectives. Financial management is viewed as one of the essential areas in business activities due to the fact that the survival, growth and expansion of the business can only be achieved where sound financial management practices employed are in line with the overall business objectives (Attom \& Mbroh 2012).

Financial management of not-revenue driven organisations are similar to that of profit making business in diverse aspect however some key contrasts move the consideration of not revenue driven association assets manager. While the Profit focus enterprises concentrate on profitability and maximizing organization's shareholders value, the not-for-profit organizations' focus is not to increase shareholders value but instead, to provide some humanitarian services. NGOs financial management is more than just keeping accurate accounting records. It additionally includes arranging, controlling and checking budgetary assets to realize higher levels of goals. In any case, Not-revenue driven associations for the most part do not have the monetary adaptability of a business venture since it relies upon asset suppliers that are not participating in a trade exchange (Blacbaud, 2011). The resources given are guided towards giving products or service to a customer other than the real asset suppliers/contributors. NGOs must exhibit its stewardship of cash receipt and other material assets donated for a particular reason must be utilized for that purpose. An aim which is stipulated by the donor or inferred in the not-for-profit's specified blueprint. The management precepts and reporting activities of a not-for-profit must ensure that these activities strongly geared towards the stewardship for every donated resource. 
Budgeting and cash management are two zones of financial management that are very important practices for not-for-profit organizations such as NGOs. It is expedient that these organizations ensure at all year round, whether it has adequate cash reserve to continue to render its services to its beneficiaries. Cash flow in not-for-profits such as NGOs can be enormously challenging to estimate, because such organization relays on proceeds from resource providers: donors, that, which cannot guarantee their services (Blacbaud, 2011). Generally, an increase in demand for a not-for-profit's services is more likely to lead to a management crisis since forecasting contribution revenue in a reliable routine yearly is difficult and undefined. For this reason, the control of expenses is a subject of augmented importance hence budgeting becomes a serious activity for a not-for-profit such as NGOs (Blacbaud, 2011). More often than not, NGOs financial management is overlooked and this has often led to abrupt liquidation of most of the NGOs. As such according to Stephenson (2003) NGOs currently must design an effective financial management tools that will ensure massive accountability to donors and different partners, gain the esteem and sureness of supporting agencies and above all help them prepare for lasting financial sustainability. Although no one model of financial management fits every organization, a well-organized NGOs financial management is a key to the organization's sustainability (Mango, 2006).

\subsection{Performance Measurement and Management of Non-profit-Organizations: (NGOs)}

Goodwin (2003) states that performance contains the real yield or aftereffects of an association as estimated against its proposed yields or destinations. Speckbacher (2003) and Taylor, Heppinstall, Liao, and Taylor (2009) ascribe that the non-profit organizations are different from other organizations in the public and private sectors in the sense that there is no profit maximization and no severe measure against which execution can be estimated. However, managers of non-profit organizations have the duty to efficiently manage donors' resources, act as overseers for these resources and also ensure successful overall performance of NGOs. Therefore, it is necessary that the managers of these organizations assess whether the organization is using the donated money effectively and efficiently and also morally to accomplish its task and future plans.

Senior administrators, financial experts and board members from not-revenue driven organizations face the test regarding what are the important variables of performance, and how should these variables be measured. Anyway the essential enthusiasm of a funder, a giver, a board member, the society, or some other partner ought to be whether the not-revenue driven (NGO) has accomplished its mission (Marc \& Adriana, 2009). To have the option to gauge that accomplishment requires an unmistakably characterized crucial technique which the examination setting for this investigation has set up. The leading practices in comprehensive not-for-profit performance measurement have shown that organizations can develop performance measurement systems that include social impact-centred measures, member-centre measures, and other non-monetary measures, along with the monetary ones. Not-for-profit organizations need a common framework (model) that not only counts the inputs, outputs, and outcomes of their programs and activities, but also (a) provides information on their success in generating positive social changes and/or member benefits (impacts), and (b) gives insight into the drivers of these changes (Marc \& Adriana, 2009) on this basis the performance of the case setting (YMCA) of this study was measured.

Several authors have provided a number of descriptions of performance measurement. Lindblad 2006 sees measurement of NGOs performance as the utilization of goals, pointers and data to evaluate these associations' intercessions and administrations. It is treated as the system for assessing representatives, groups and the whole association (Ferreira \& Otley, 2009). Mill operator 2007 likewise puts NGOs performance estimation as a methodology of appraisal that assesses a projects sway in terms of productivity and viability. Carman (2007) declares that estimating performance includes an efficient methodology of assessing a projects yields, inputs and effects. Access to resources to ensure survival should not be the sole dimension for measuring NGOs performance. Likewise, Kareithi and Lund (2012) states that the principal goal of NGOs is focused at the ideal objectives satisfying their receivers and the improvement in their various communities. Therefore, the assessment of NGOs should mainly be measured on how productive they have been in achieving their targeted social objectives. Usually, NGOs evaluate their performance by setting performance models and then proceed to gather information related to the established indicators. The normal performance pointers mostly utilized by NGOs involves viability, raising support, costs, fulfilment of recipients as well as competence (Carman, 2007). Likewise, Teelken (2008) determined four (4) performance dimensions which are: efficacy, economy, efficiency and effectiveness to be used to evaluate the operation of NGOs. Also, Benjamin and Misra (2006) included that, in surveying NGOs performance, the attention ought to be on four fundamental markers which are inputs, yields, results and effects.

These various above mentioned expert opinions on NGOs performance measurement are not different from the Program Logical Model introduced by Kellogg Foundation in 1998 (Kellogg, 2004) and the InputImpact Model by Marc and Adriana (2009) on nonprofit performance measurement which states that not just resources (services the program provides, the clients it serves or the cases it treats, its intended results, and the logic behind how the use of resources in the program activities is expected to produce results) but also putting the mission and vision statements of the organization at the core, and also places strategy, 
organizational structure, systems and also internal environment among the inputs: theories from which the conceptual framework of performance measurement for this study was couched.

\subsection{Relationship between NGOs Performance and Financial Management}

Efficient financial management is the backbone of any entity's growth drive or attainment of high performance. The financial management function on top notch sets the bedrock for development, advancement and sustainability (Aldaba, 2002). As indicated by Easterly and Rebelo (1993) development and advancement exchanges would be inadequate without the notice of monetary management, which, exemplified on the full scale level as the sourcing for and employments of fiscal resources in accordance with improvement purposes, is caught as the financial management function on the small scale level.

It is more certain that financial management systems continue to be of much significance to business success; either for profit or otherwise. Several studies have shown that the nature of management, accounting information employed within the small business sector and other resourced managed organizations such as NGOs has a positive relationship with an entity's performance (Raymond and Magnenat-Thalmann (1982); Holmes and Nicholls (1989); Nayak and Greenfield (1994) and Lybaert (1998)) Also. as indicated by SontagPadilla, Morganti, and Staplefoote (2012) in their exploration on fiscal solvency of magnanimous associations, powerful financial administration actions was found fundamental in enhancing transparency, efficiency, accuracy, accountability; these which are performance indicators, which enable an organization to achieve its objectives.

The success of a business depends on how well it harnesses everyone to work to toward a common goal whiles considering the differences among members (Brealey \& Myers, 2003). Clark (1991) affirms that one of the major drivers of efficiency is the manner of utilization of the capital and the funds that the NGO sector accumulates through various sources for carrying out its work. Statistics show that out of more than 1.2 million NGOs working in India, just $3 \%$ are having the option to do valuable grass-root level work (ICONGO, 2002 overview) hence poor performance. Also, NGO establishments typically tend to have high administrative costs of nearly $60 \%$ and above. Thus, only $10-20 \%$ of the funds are utilized for effective developmental work. These performance threatening practices could be associated to lack of stringent financial management norms/practices. This, again, shows how devastating an organization will be when its financial management systems, controls or regulations are compromised.

\section{Research Methodology}

This study utilized a case study design. The target population for the study was the YMCA Ghana organization's staff drawn from different departments of its headquarters. 48 respondents were sampled from the accounting and finance, internal audit, Human resource, procurement, Management including Field officers and administration using a defined non-random sampling method. The study employed both primary and secondary data using questionnaires and interviews, and organisational records respectively. A blend of quantitative and qualitative techniques of data analyses was used. Quantitative analysis was applied on the quantitative data to give meaning to them while qualitative analysis was applied on non-quantitative questions and variables. Data was analysed using SPSS Statistics Version 21 and Microsoft Excel for graphs and figures.

\section{Data Presentation, Analysis and Discussion}

This section summarizes the data collected and the statistical method of analysis, using the methodology adopted in the prior chapter. The 48 respondents engaged in this study were: one (1) Finance Director; one (1) Directors at the Internal Audit Unit; one (1) Director (Management); one (1) manager (HR); three (3) staff of the Internal Audit Unit; seven (7) from Accounting and Finance Department; four (4) staff from the Human Resource Department; three (3) from general administration; nine (9) staff from the Procurement and Logistics Department; and eighteen (18) Field officers.

\subsection{Demographic Information of the Respondents}

The statistic qualities of the respondents were examined using gender, age, Educational background and years of service of the respondents. The results from the survey are shown in Table 1.

Table 1 shows that more males $32(66.7 \%)$ than females $16(33.3 \%)$ partook in this study which could also mean more males are engaged in the operations of YMCA Ghana than females which might be due to tough nature of the job. The table also indicate that majority of the respondents engaged in this study were those in the 35-40 age group representing as much as $24(50.0 \%)$ of the total response rate. Followed by those in the age bracket of 25-30 years who were also represented by $14(29.2 \%)$. Respondents who were above the age of 40 years were represented by $8(16.7 \%)$ while those from 20 to 25 years were also represented by $2(4.2 \%)$. The table also shows that that majority 14(29.2\%) of the respondents have Undergraduate (Bachelor's) Degree as their highest educational qualifications. This was followed by those with Professional qualification and master's degree who had the same number of respondents of $13(27.1 \%)$. The respondents who had Diploma as their most elevated educational credential were $7(14.6 \%)$ while only 1 respondent had high school qualification representing $2.1 \%$ of the total response rate. Based on the analysis of Table 1 , it could be inferred that YMCA 
Ghana is dominated by Bachelor's Degree Holders with a substantial majority haven professional and master qualification. With regards to years of service, majority $29(60.4 \%)$ of the respondents in this study have worked with YMCA Ghana for 2-5 years. Those who have worked there for 6-10 years were 17 representing $35.4 \%$ whiles those who have worked there for more than 10 years and those who have worked there for less than 2 years had the same number of respondents $1(2.1 \%)$. This indicates that most of the respondent engaged in this study were experienced about the operations of YMCA Ghana and therefore could provide valid and reliable data for this study.

Table-1. Demographical characteristics of the sample.

\begin{tabular}{|c|c|c|c|c|c|}
\hline Variables & Type & Frequency & Percent & $\begin{array}{c}\text { Valid } \\
\text { Percent }\end{array}$ & $\begin{array}{c}\text { Cumulative } \\
\text { Percent }\end{array}$ \\
\hline Gender & Male & 32 & 66.7 & 66.7 & 66.7 \\
\hline & Female & 16 & 33.3 & 33.3 & 100 \\
\hline Total & & 48 & 100 & 100 & \\
\hline \multirow[t]{4}{*}{ Age (years) } & $20-25$ & 2 & 4.2 & 4.2 & 4.2 \\
\hline & $25-30$ & 14 & 29.2 & 29.2 & 33.3 \\
\hline & $35-40$ & 24 & 50.0 & 50.0 & 83.3 \\
\hline & 40 and Over & 8 & 16.7 & 16.7 & 100.0 \\
\hline Total & & 48 & 100.0 & 100.0 & \\
\hline \multirow[t]{5}{*}{ Education } & High School & 1 & 2.1 & 2.1 & 2.1 \\
\hline & Diploma & 7 & 14.6 & 14.6 & 16.7 \\
\hline & Undergraduate & 14 & 29.2 & 29.2 & 45.8 \\
\hline & Professional & 13 & 27.1 & 27.1 & 72.9 \\
\hline & Masters & 13 & 27.1 & 27.1 & 100.0 \\
\hline Total & & 48 & 100.0 & 100.0 & \\
\hline \multirow[t]{4}{*}{ Years of Service } & Less than 2 years & 1 & 2.1 & 2.1 & 2.1 \\
\hline & $2-5$ years & 29 & 60.4 & 60.4 & 62.5 \\
\hline & $6-10$ years & 17 & 35.4 & 35.4 & 97.9 \\
\hline & Over 10 years & 1 & 2.1 & 2.1 & 100.0 \\
\hline Total & & 48 & 100.0 & 100.0 & \\
\hline
\end{tabular}

\subsection{Functionality of Financial Management Systems}

To examine the functionality of financial management systems of YMCA Ghana, data were gathered on the following indicators: Funding Agreement (FA); Bank Account, Cash Handling and Transaction (BCT); Stock and Inventory Management (SIM); Financial Management Staff/Responsibility (FMSR); Fiscal Planning and Budgeting (FPB). The respondents were approached to demonstrate the degree to which they concur or differ to financial management usefulness utilizing a 5-point Likert scale translated as: 1emphatically concur, 2-concur, 3 indifferent, 4-deviate, and 5-unequivocally oppose this idea.

\subsubsection{Funding Agreement ( FA)}

Table 2 illustrates the frequencies and means of the responses received on the level of agreement and disagreement on the Funding Agreement variables used in this study. The table gives the mean or average view of respondents on each of the seven variables used to assess the views of respondents on Funding Agreement at YMCA Ghana. They are 1.44, 1.40, 1.58, 1.71, 1.60, 1.83 and 1.79 for the statements in FA-1, FA-2, FA-3, FA-4, FA-5, FA-6 and FA-7 respectively. This gives a total average mean of 1.62, approximately 2. This implies that, on the average, majority of respondents "agree" that: Agreement outlines funding of project(s); Agreement outlines activities to achieve deliverables; Agreement clearly mentions management of funds and procurement of goods; Agreement clearly mentions reporting procedures: Monthly, quarterly, annually; Agreement clearly specifies funds allocated for individual activities; Agreement clearly mentions all deadlines; Agreement clearly mentions funds release schedule.

Again, the standard deviation of the individual measures of Financial Agreement in Table 2 shows that among the seven (7) statements used to measure clarity of Financial Agreement, the most important statement is that: agreement outlines activities to achieve deliverables with mean of 1.40 and standard deviation of 0.610 even though all the statements are important according to the respondents. These findings are in line with Theunis and Erika (2011) and FUNDSFORNGOs effective practices of NGOs funding to ensure sustainability. They mentioned that, one of the most important elements of an effective funding agreement is the ability to naturally and precisely mention all deliverables: quantifiable and qualitative, concurred between the contributor and the NGO.

Key to Table 2

FA -1: Agreement outlines funding of project(s). 
FA-2: Agreement outlines activities to achieve deliverables.

FA-3: Agreement clearly mentions management of funds and procurement of goods.

FA-4: Agreement clearly mentions reporting procedures: Monthly, quarterly, annually.

FA-5: Agreement clearly specifies funds allocated for individual activities.

FA-6: Agreement clearly mentions all deadlines.

FA-7: Agreement clearly mentions funds release schedule.

Table-2. Funding agreement (FA).

\begin{tabular}{|c|c|c|c|c|c|c|c|c|}
\hline $\begin{array}{l}\text { Funding } \\
\text { agreement }\end{array}$ & & & & & & & & Standard \\
\hline Variables & & & & & & Total & Mean & Deviation \\
\hline & Strongly & & & & $\begin{array}{c}\text { Strongly } \\
\text { disagree }\end{array}$ & & & \\
\hline & Agree & Agree & Neutral & Disagree & 5 & & & \\
\hline & 1 & 2 & 3 & 4 & & & & \\
\hline FA-1 & 28 & 19 & 1 & - & - & 48 & 1.44 & 0.542 \\
\hline FA-2 & 32 & 13 & 3 & - & - & 48 & 1.4 & 0.61 \\
\hline FA-3 & 23 & 22 & 3 & - & - & 48 & 1.58 & 0.613 \\
\hline FA-4 & 22 & 18 & 5 & 3 & - & 48 & 1.71 & 0.743 \\
\hline FA-5 & 22 & 23 & 3 & - & - & 48 & 1.6 & 0.61 \\
\hline FA-6 & 17 & 22 & 9 & - & - & 48 & 1.83 & 0.724 \\
\hline FA-7 & 21 & 16 & 9 & 2 & - & 48 & 1.79 & 0.798 \\
\hline \multicolumn{7}{|c|}{ Total } & 11.35 & \\
\hline \multicolumn{7}{|c|}{ Total average mean score $(=$ Total $/ 7)$} & 1.62 & \\
\hline
\end{tabular}

4.2.2. Bank Account, Cash Handling and Transaction (BCT)

Table 3 presents the frequencies and means of variables used to assess Bank Account, Cash Handling and Transactions at YMCA Ghana. The table gives the mean or average of opinions of respondents on each of the eleven variables on Bank Account, Cash Handling and Transactions. They are 1.13, 1.27, 1.40, 2.00, 1.98, 1.73, $1.60,1.81,1.65,1.81$ and 1.58 for the statements in BCT-1, BCT-2, BCT-3, BCT-4, BCT-5, BCT-6, BCT-7, BCT-8, BCT-9, BCT-10 and BCT-11 respectively. This gives a total average mean of 1.63, approximately 2. This implies that, on the average, majority of respondents "agree" that the authoritative dimensions of Bank Account, Cash Handling and Transactions mechanisms/frameworks by Theunis and Erika (2011), Mango (2006) and FUNDSFORNGOs for NGOs and other not-for-profit organizations are properly upheld at YMCA Ghana hence denoting that the current FM practices/systems of YMCA Ghana is worthy.

Table-3. Bank account, cash handling and transaction (BCT).

\begin{tabular}{|c|c|c|c|c|c|c|c|c|}
\hline \multirow{2}{*}{$\begin{array}{c}\text { Bank, Cash } \\
\text { and } \\
\text { Transaction } \\
\text { variables }\end{array}$} & \multicolumn{5}{|c|}{ Frequency } & \multirow[t]{2}{*}{ Total } & \multirow[t]{2}{*}{ Mean } & \multirow{2}{*}{$\begin{array}{l}\text { Standard } \\
\text { deviation }\end{array}$} \\
\hline & $\begin{array}{c}\text { Strongly } \\
\text { agree } \\
1\end{array}$ & $\begin{array}{c}\text { Agree } \\
2\end{array}$ & $\begin{array}{c}\text { Neutral } \\
3\end{array}$ & $\begin{array}{c}\text { Disagree } \\
4\end{array}$ & $\begin{array}{c}\text { Strongly } \\
\text { disagree } \\
5\end{array}$ & & & \\
\hline BCT-1 & 42 & 6 & - & - & - & 48 & 1.13 & .334 \\
\hline ВCT-2 & 35 & 13 & - & - & - & 48 & 1.27 & .449 \\
\hline ВСТ-3 & 29 & 19 & - & - & - & 48 & 1.40 & .494 \\
\hline BCT-4 & 12 & 24 & 12 & - & - & 48 & 2.00 & .715 \\
\hline ВСТ-5 & 13 & 22 & 11 & 2 & - & 48 & 1.98 & .737 \\
\hline ВСТ-6 & 18 & 25 & 5 & - & - & 48 & 1.73 & .644 \\
\hline ВСТ-7 & 22 & 23 & 3 & - & - & 48 & 1.60 & .610 \\
\hline ВCТ-8 & 19 & 19 & 8 & 2 & - & 48 & 1.81 & .762 \\
\hline ВСТ-9 & 19 & 27 & 2 & - & - & 48 & 1.65 & .565 \\
\hline BCT-10 & 15 & 27 & 6 & - & - & 48 & 1.81 & .641 \\
\hline BCT-11 & 22 & 24 & 2 & - & 2 & 48 & 1.58 & .577 \\
\hline \multicolumn{7}{|c|}{ Total } & 17.96 & \\
\hline \multicolumn{7}{|c|}{ Total average mean score $(=$ Total/ 11$)$} & 1.63 & \\
\hline
\end{tabular}

Key to Table 3

BCT-1: Bank accounts are opened in nationally recognized banks for all project funds.

BCT-2: There is clearly stated authorized signatory (ies) for all banking instruments.

BCT-3: Finance management policy clearly states who is/are responsible for managing bank transactions. 
BCT-4: Cash transactions are turn if there should arise an occurrence of insignificant costs and when/where banking administrations are not available.

BCT-5: Closing balance money are recorded in the everyday money balance segment and signed by accountant.

BCT-6: A staff responsible for handling cash dully filled up and sign cash withdrawal form to be used to withdraw cash from bank when there is the need.

BCT-7: Payment voucher is used to make cash payments and approved by responsible authority (ies) before payment.

BCT-8: It is mandatory to verify the cashbook balance at the defined closing period and any discrepancy noticed is recorded and reported to person concerned.

BCT-9: For payouts form petty cash, a petty cash request form is completed and recipient sign request form upon receipt of cash.

\subsubsection{Stock and Inventory Management (SIM)}

Table 4 in the next page presents the frequencies and means of responses received on Stock and Catalogue Management. For each of the statement or variables under Stock and Inventory Management: SIM-1, SIM-2, SIM-4 and SIM-5, respondents indicated the extent to which they agree or disagree. The table shows that for each of the statements, majority "Agree" that there is efficient stock and Inventory Management at YMCA Ghana. The mean of 1.70 , which is approximately 2 for all the five statements, confirms that on the average, respondents "agree" to the fact that stock and Inventory are managed well at YMCA Ghana. This implies that, the standard NGO and other non-profit dimensions for Stock and Inventory Management mechanisms/frameworks established by Theunis and Erika (2011), Mango (2006) and FUNDSFORNGOs are properly upheld at YMCA Ghana hence denoting that the current FM practices/systems of YMCA Ghana is good enough to improve on the organizations' performance.

Table-4. Stock and Inventory Management (SIM).

\begin{tabular}{|c|c|c|c|c|c|c|c|c|}
\hline \multirow{2}{*}{$\begin{array}{c}\text { Stock and } \\
\text { Inventory } \\
\text { Management } \\
\text { variables }\end{array}$} & \multicolumn{5}{|c|}{ Frequency } & \multirow[t]{2}{*}{ Total } & \multirow[t]{2}{*}{ Mean } & \multirow{2}{*}{$\begin{array}{l}\text { Standard } \\
\text { deviation }\end{array}$} \\
\hline & $\begin{array}{c}\text { Strongly } \\
\text { agree } 1\end{array}$ & $\begin{array}{c}\text { Agree } \\
2\end{array}$ & $\begin{array}{c}\text { Neutral } \\
3\end{array}$ & $\begin{array}{c}\text { Disagree } \\
4\end{array}$ & $\begin{array}{c}\text { Strongly } \\
\text { disagree } \\
\mathbf{5} \\
\end{array}$ & & & \\
\hline SIM-1 & 35 & 13 & - & - & - & 48 & 1.27 & .449 \\
\hline SIM-2 & 23 & 23 & 2 & - & - & 48 & 1.56 & .580 \\
\hline SIM-3 & 13 & 20 & 12 & 3 & - & 48 & 2.04 & .771 \\
\hline SIM-4 & 10 & 26 & 11 & - & 1 & 48 & 2.08 & .794 \\
\hline SIM-5 & 23 & 23 & ${ }^{2} 2$ & - & - & 48 & 1.56 & .580 \\
\hline \multicolumn{7}{|l|}{ Total } & 8.51 & \\
\hline \multicolumn{7}{|c|}{ Total average mean score $(=$ Total $/ 5)$} & 1.70 & \\
\hline
\end{tabular}

Source: Field survey, January 2019.

Key to Table 4

SIM-1: Maintains stock register by recording all goods purchased and stored to prevent excess purchases and wastage.

SIM-2: Stock \& inventory register is audited and monitored periodically.

SIM-3: Quotations are obtained from 3-4 suppliers before finalizing on supplier for purchase based on quote and reliability.

SIM-4: Past performance, reputation and availability are emphasized when selecting supplier.

SIM-5: Authorize person(s) is/are dully assigned to manage all stock records and its aligned function.

\subsubsection{Financial Management Staff and Responsibilities (FMSR)}

Table 5 presents the frequencies and means of responses received on Financial Management staff and their responsibility as an indicator of financial management functionality at YMCA Ghana. For each of the statement or variables FMSR-1, FMSR-2, FMSR-3, FMSR-4, FMSR-5, FMSR-6, and FMSR-7, respondents indicated the extent to which they agree or disagree. The mean of 1.57 , approximately 2 for all the seven statements indicates that on the average, respondents "agree" to the fact that financial management staff are of high quality and responsible which could in turn enhance financial management functionality at YMCA Ghana. This is, again, an implication that the quality and responsibility of financial management staff in YMCA Ghana is of high standard, efficient and conforms to Theunis and Erika (2011), Mango (2006) and FUNDSFORNGOs' elements of NGOs and non-profit making organizations' financial management frameworks for NGOs financial management staff and their duties.

Key to Table 5

FMSR-1: There is governing body/executive board which comprises members from different committees of the organization for example, account, public relations and venture and assumes a lead job in financial division. 
FMSR-2: There is board of members who are ultimately responsible for the financial aspects of the organization to ensures that everything is undertaken in proper order.

FMSR-3: A finance manager whose is the head of the finance committee and plays supervisory functions and monitoring responsibilities.

FMSR-4: The finance manager assists and guides the board by providing relevant financial information during budgeting, accounts to donors and other decision-making activities.

FMSR-5: There is financial assistants whose main responsibility is to report to the finance manager and implement work, as and when directed.

FMSR-6: Administrative manager(s) who is/are knowledgeable and take overview and control of the appointment, inventories, stocks, and all other non-specific activities.

FMSR-7: Administrative/cash assistant whose responsibilities spread across various spectrums of duties, finance being one.

Table-5. Financial management staff and responsibilities (FMSR).

\begin{tabular}{|c|c|c|c|c|c|c|c|c|}
\hline \multirow{2}{*}{$\begin{array}{c}\text { FMSR } \\
\text { variables }\end{array}$} & \multicolumn{5}{|c|}{ Frequency } & \multirow[t]{2}{*}{ Total } & \multirow[t]{2}{*}{ Mean } & \multirow{2}{*}{$\begin{array}{l}\text { Standard } \\
\text { deviation }\end{array}$} \\
\hline & $\begin{array}{c}\text { Strongly } \\
\text { agree } \\
1\end{array}$ & $\begin{array}{c}\text { Agree } \\
2\end{array}$ & $\begin{array}{c}\text { Neutral } \\
3\end{array}$ & $\begin{array}{c}\text { Disagree } \\
4\end{array}$ & $\begin{array}{c}\text { Strongly } \\
\text { disagree } \\
5\end{array}$ & & & \\
\hline FMSR-1 & 37 & 11 & - & - & - & 48 & 1.23 & .425 \\
\hline FMSR-2 & 32 & 15 & 1 & - & - & 48 & 1.35 & .526 \\
\hline FMSR-3 & 26 & 21 & 1 & - & - & 48 & 2.08 & 4.438 \\
\hline FMSR-4 & 27 & 19 & 2 & - & - & 48 & 1.48 & .583 \\
\hline FMSR-5 & 23 & 24 & 1 & - & - & 48 & 1.54 & .544 \\
\hline FMSR-6 & 21 & 24 & - & - & 3 & 48 & 1.56 & .501 \\
\hline FMSR-7 & 19 & 24 & 4 & 1 & - & 48 & 1.73 & .707 \\
\hline \multicolumn{7}{|l|}{ Total } & 10.97 & \\
\hline \multicolumn{7}{|c|}{ Total average mean score $(=$ Total $/ 7$ ) } & 1.56 & \\
\hline
\end{tabular}

4.2.5. Financial Planning and Budgeting (FPB)

Table 6 displays the frequencies and means expectations of respondents with regards to the nine variables used to assess Financial Planning and Budgeting: FPB-1, FPB-2, FPB-3, FPB-4, FPB-5, FPB-6, FPB-7, FPB8 and FPB-9. The overall average of responses on Financial Planning and budgeting is 1.85, approximately 2. That is, the respondents "agree" that there is functional financial planning and budgeting system at work in the organization. This implies that, there are structured policies and mechanisms on financial planning and budgeting which effectively affects the financial management practices at YMCA Ghana. This well-structured financial planning and budgeting frameworks recorded at YMCA Ghana are not different from Theunis and Erika (2011) prescribed NGOs' financial planning and budgeting as a component of NGOs' financial management mechanisms.

Table-6. Financial Planning and Budgeting (FPB)

\begin{tabular}{|c|c|c|c|c|c|c|c|c|}
\hline \multirow{2}{*}{$\begin{array}{c}\text { Financial } \\
\text { Planning } \\
\text { and } \\
\text { Budgeting } \\
\text { variables }\end{array}$} & \multicolumn{5}{|c|}{ Frequency } & \multirow[b]{2}{*}{ Total } & \multirow[b]{2}{*}{ Mean } & \multirow[b]{2}{*}{$\begin{array}{l}\text { Standard } \\
\text { deviation }\end{array}$} \\
\hline & $\begin{array}{c}\text { Strongly } \\
\text { agree } \\
1\end{array}$ & $\begin{array}{c}\text { Agree } \\
\underset{2}{ }\end{array}$ & $\begin{array}{c}\text { Neutral } \\
3\end{array}$ & $\begin{array}{c}\text { Disagree } \\
4\end{array}$ & $\begin{array}{c}\text { Strongly } \\
\text { disagree } \\
\mathbf{5}\end{array}$ & & & \\
\hline FPB-1 & 31 & 15 & 2 & - & - & 48 & 1.40 & .574 \\
\hline FPB-3 & 15 & 26 & 6 & - & 1 & 48 & 1.88 & .789 \\
\hline FPB-4 & 17 & 20 & 8 & 3 & - & 48 & 1.88 & .761 \\
\hline FPB-5 & 22 & 18 & 8 & - & - & 48 & 1.71 & .743 \\
\hline FPB-6 & 29 & 17 & - & 2 & - & 48 & 1.42 & .539 \\
\hline FPB-7 & 23 & 18 & 7 & - & - & 48 & 1.67 & .724 \\
\hline \multicolumn{7}{|c|}{ Total average mean score (=Total/9) } & 1.64 & \\
\hline
\end{tabular}

Key to Table 6

FPB-1: Budget is prepared for each activity giving break up of sub-activities and related costs.

FPB-2: Budgets capture all the required costs for specific activities only.

FPB-3: Budgets are approved before incorporation into financial Plans.

FPB-4: Program objectives along with activity plans are completed before budgeting. 
FPB-5: Whole project/departmental team are involved in budgeting process.

FPB-6: All expenses are reviewed against the budget on a monthly basis.

FPB-7: Project management verifies quarterly reports against budget, examine causes for alteration and take appropriate action.

FPB-8: Project management verifies quarterly reports against budget analyze causes for variance and take appropriate action.

FP9-9: Budgets for subsequent year(s) take into consideration cost increases due to inflation, exchange rates, etc.

Figure 1 summarizes respondents' mean/averages of the five indicators of functionality of financial management and control systems at YMCA Ghana namely: Funding Agreement (FA); Bank Account, Cash Handling and Transaction (BCT); Stock and Inventory Management (SIM); Financial Management Staff/Responsibility (FMSR); Financial Planning and Budgeting (FPB). The figure shows pictorial perspective on mean for each measurement and the score thereof. It is glaring from the bar chart that the quality of Financial Management staff and their responsibility is the most effective financial management indicator at YMCA Ghana even though all the indicators function well in the organization. The average of the responses for all the five indicators of financial management systems is 1.67 (given by the mean of the average for all the five indicators of financial management). This means that the respondents "agree" that the functional financial management and control system at YMCA Ghana is effective.

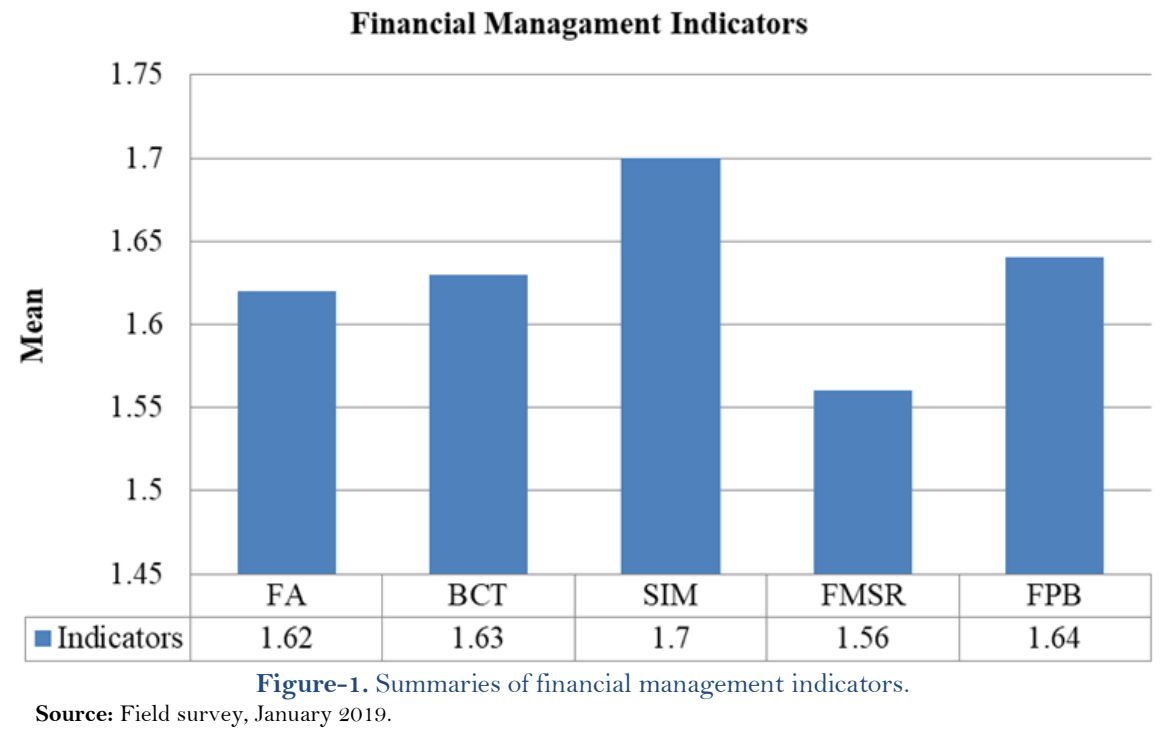

4.2.6. Performance Review of YMCA Ghana

To assess the performance at YMCA Ghana, the respondents were presented with ten (10) key not for profit organizations': NGOs performance indicators to indicate the extent to which they agree or disagree to the performance indicators using a 5-point Likert scale interpreted as: 1- strongly agree, 2- agree, 3- neutral, 4- disagree, and 5- strongly disagree. The responses have been analysed in Table 7.

Table 7 presents the frequencies and means of responses received on ten (10) Non-profit: NGOs' performance measures when they were employed as performance review of YMCA Ghana. For each of the statement or variables PR-1, PR-2, PR-3, PR-4, PR-5, PR-6, PR-7, PR-8, PR-9 and PR-10, respondents indicated the extent to which they agree or disagree. The total average of 1.53, approximately 2 for all the ten statements indicates that on the average, respondents "agree" to the fact that the current financial management system/controls being practiced at YMCA Ghana have significantly contributed to the various commendable successes/accomplishments that the organization has been credited with for the past years. Samuel Manu Kofi: a professor at the University of Cape Coast, Ghana expressed a sentiment that "NGOs have a reputation for being short-lived when they come to Ghana, do something helpful and leave again. While longevity is not always necessary, having a substantial impact is." Although many NGOs have come to Ghana and they have left, but YMCA Ghana is still alive and active for more than 30 years of operation and still impacting lives and societies. This achievement, which can be said, among other things, that it's as a result of the organizations good financial management and controls framework being practiced. This results also conforms to Sontag-Padilla et al. (2012) in their study on financial sustainability for non-profit organizations which they mentioned that effective financial management practices is essential in enhancing transparency, efficiency, accuracy, accountability; these which are performance indicators, which enable an 
organization to achieve its objectives such as growth, development and sustainability to impact on needy lives and impoverished and neglected societies.

Key to Table 7

PR-1: Existing financial management controls are capable of increasing fundraising efficiency and funds growth.

PR-2: Existing Financial management controls have the ability to ensure financial transparency to Stakeholders.

PR-3: Current Financial management controls could have led to increase in quality of services provided.

PR-4: The Financial management regulations have positively influenced the level of satisfaction of beneficiaries and stakeholders of YMCA Ghana's projects/programs.

PR-5: Financial management controls have ensured increased in projects/programs finance efficiency (financial resources are best used to achieve required planned outputs).

PR-6: Financial management regulations have ensured projects/programs non- financial efficiency (nonfinancial resources such as time, staff and expertise are best used to achieve planned outputs).

PR-7: There has been increase in networking, relevance and satisfaction among partners (Local Government, bilateral organizations, etc.) due to the current financial management controls practiced.

PR-8: The current financial management controls ensure that financial information needed for Management decision making and stakeholders' perusal are quality.

PR-9: Existing Financial management controls are capable of ensuring prevention, if not, decrease in fraudulent fiscal reporting frameworks.

PR-10: Financial management controls have contributed to increase in Impact performance (The Long-term positive effects/consequences of YMCA Ghana's programs /activities).

\begin{tabular}{|c|c|c|c|c|c|c|c|c|}
\hline \multirow{2}{*}{$\begin{array}{c}\text { Performance } \\
\text { Review } \\
\text { variables }\end{array}$} & \multicolumn{5}{|c|}{ Frequency } & \multirow[t]{2}{*}{ Total } & \multirow[t]{2}{*}{ Mean } & \multirow{2}{*}{$\begin{array}{l}\text { Standard } \\
\text { deviation }\end{array}$} \\
\hline & $\begin{array}{c}\text { Strongly } \\
\text { agree } 1\end{array}$ & $\begin{array}{c}\text { Agree } \\
2\end{array}$ & $\begin{array}{c}\text { Neutral } \\
3\end{array}$ & $\begin{array}{c}\text { Disagree } \\
4\end{array}$ & $\begin{array}{c}\text { Strongly } \\
\text { disagree5 }\end{array}$ & & & \\
\hline PR-1 & 23 & 22 & 1 & 2 & - & 48 & 1.50 & .546 \\
\hline PR-2 & 27 & 20 & 1 & - & - & 48 & 1.46 & .544 \\
\hline PR-3 & 21 & 27 & - & - & - & 48 & 1.50 & .505 \\
\hline PR-4 & 25 & 20 & 3 & - & - & 48 & 1.54 & .617 \\
\hline PR-5 & 20 & 26 & 2 & - & - & 48 & 1.63 & .570 \\
\hline PR-6 & 19 & 25 & 2 & 2 & - & 48 & 1.60 & .574 \\
\hline PR-7 & 28 & 19 & 1 & - & - & 48 & 1.44 & .542 \\
\hline PR-8 & 30 & 17 & 1 & - & - & 48 & 1.40 & .536 \\
\hline PR-9 & 23 & 25 & - & - & - & 48 & 1.56 & .580 \\
\hline PR-10 & 21 & 20 & 4 & 2 & 1 & 48 & 1.65 & .729 \\
\hline \multicolumn{7}{|l|}{ Total } & 15.28 & \\
\hline \multicolumn{7}{|c|}{ Total average mean score (=Total/10) } & 1.53 & \\
\hline
\end{tabular}

Figure 2 summarizes respondents' mean/averages of the probability that the five indicators of functionality of the current financial management and control systems at YMCA Ghana has been an influential factor of the organization's current remarkable performance standard. The figure indicates pictorial perspective on mean for each measurement and the score thereof.

It is glaring from the bar chart that the ability of the current financial management control systems to ensure quality information needed for management decision making and stakeholders perusal is the most obvious performance review indicator at YMCA Ghana followed closely by, also, the ability of the current financial management controls in YMCA Ghana to have increased its networking, relevance and satisfaction among its partners and the realization of projects/programs non-financial efficiency coming next even though all the indicators are being recorded in the organization. The average of the responses for all the ten dimensions of performance review is 1.53 (given by the mean of the average for all the ten measures of performance).

This means that the respondents "agree" that the current financial management and control system being practiced at YMCA Ghana is effective enough to have improved on and contributed to the organization's remarkable achievements. 


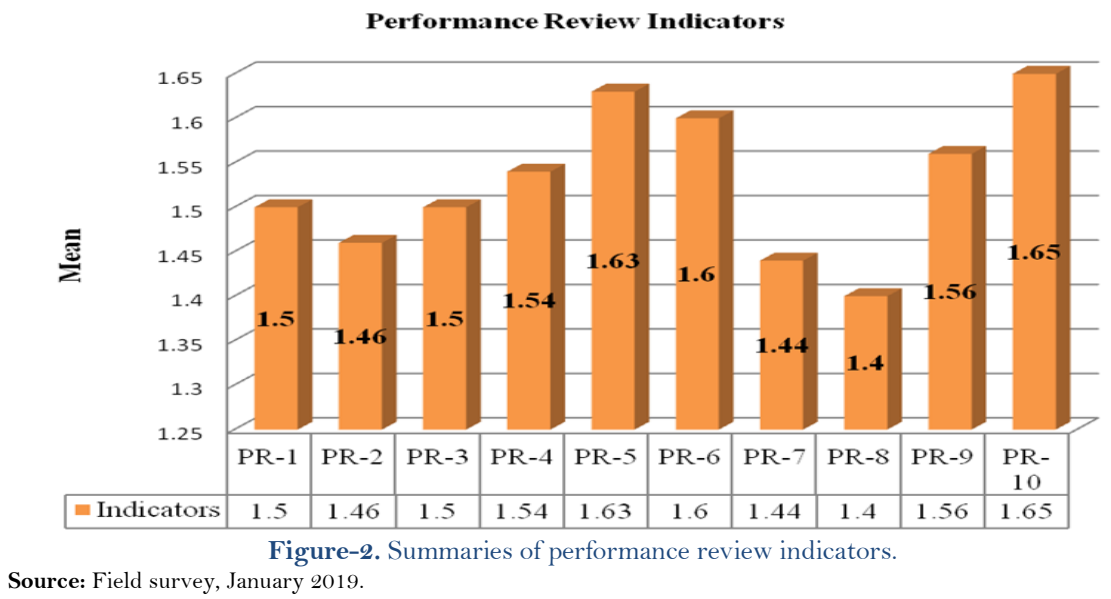

\section{Conclusion and Recommendations}

The study sought to investigate into how to improve performance of NGOs in Ghana by sound financial management systems and practices using the case of YMCA Ghana. A sample of 48 respondents was used for the study. The following objectives were set for the study; to examine the functionality of financial management control systems in YMCA Ghana, to identify any possible challenges that hinders the implementation of sound financial management control systems, to review the performance of YMCA Ghana. To achieve the set objectives, SPSS tool and Microsoft excel were employed on the dataset for the analysis.

The study revealed that, the quality of Financial Management staff and their responsibility is the most effective financial management indicator at YMCA Ghana even though all the other indicators which are Funding Agreement, Bank, Cash handling and Transactions, Stock inventory and management and financial planning and budgeting function well in the organization. The average of the responses for all the five indicators of financial management systems was 1.67 signifying that the respondents "agreed" that the current financial management and control system at YMCA Ghana is effective.

The study also established that the ability of the current financial management control systems to ensure quality information needed for management decision making and stakeholders perusal which subsequently build trust is the most obvious performance review indicator at YMCA Ghana followed closely by, the influential role of the current financial management controls in YMCA performance improvement via increase in its networking, relevance and satisfaction among its partners and the realization of projects/programs nonfinancial efficiency. The average of the responses for all the ten dimensions of performance review was 1.53 implying that the respondents "agree" that the functional financial management and control system at YMCA Ghana is effective enough to have improved on and contributed to the organization's ability to achieve its objectives of impacting children's lives and their families. However, it is also evident in this study that YMCA Ghana faces some shortcomings in its financial management practices: all paper and pen (traditional) ways of accounting, record keeping and reporting; irregular external audit review of financial and accounting statements/records.

Despite the few outline challenges in YMCA financial management framework, YMCA's financial management and control mechanisms is still worthy to be recommended to and emulated by other NGOs (local and international) in Ghana. NGOs play an imperative role in economic development of struggling economies. It is critical to be aware of the impact of NGOs in the growth of the economy, which includes creation of jobs, improving of standard of living, easing poverty and attaining of sustainable development goals. However, for NGOs to succeed, effective financial management practices should be employed. This includes quality of financial information and the medium of reporting to ensure accountability, periodic external auditing to control the tendency of preparing fraudulent financial information, employing the services of qualified and ethical personnel's to man operations. NGOs should also adopt internal control measure that emphasize on cost effective monitoring, evaluation, accountability and learning(MEAL) systems that effectively plans and tracks results in a timely manner for further action planning. The researchers are certain of the fact that when the above recommendations are well executed, it will help improve the performance of NGOs not only in Ghana but over the world. Hence, achieve the sustainable development goals for a world without hunger and malnutrition, poverty, lack of education and health facilities, child exploitation and maltreatment among others.

\section{References}

Abdul-Gafaru, A., \& Quantson, R. (2008). The varying role of CSOS in public strategy making in Ghana Institute for Democratic Governance: Policy Research Series, No. 6.

Aldaba, F. T. (2002). Philippine NGOs and multistakeholder partnerships: Three case studies. Voluntas: International Journal of Voluntary and Nonprofit Organizations, 13(2), 179-192. 
Alhassan, M., Faustina, O., \& Evans, A. (2018). Financial misconduct and risk of financial misconduct of NGOs in Ghana: Viewpoint of donors. Theoretical Journal of Economic Studies, school of Finance, Funding and Accountancy Bucharest, "Dimitri Cant emir" Christian University Bucharest, 4(3), 146-153.

Allis, R. P. M. (2004). Financial management: Ratio analysis zero to one million. New York: McGraw-Hill.

Amanor, K., Denkabe, A., \& Wellard, K. (1993). Ghana: Country overview. Non-governmental organizations and the State in Africa. London and New York: Routledge.

Atingdui, L., Anheier, H. K., \& Sokolowski, S. W. (1997). The non-profit sector in Ghana. In Anheier, H.K. and Salamon, L.M. (Eds.), Thenonprofit sector in the developing world (pp. 158-197). Manchester: Manchester University Press.

Attom, B. E., \& Mbroh , J. K. (2012). Financial management made easy: A self-tuition approach (pp. 1). Accra: Adwinsa Publications (Gh.) Limited.

Ayom, A. A. (2013). Internal controls and performance in non-governmental organizations: A case study of management sciences for health South Sudan. Unpublished Masters Dissertation, University of Nairobi.

Benjamin, L. M., \& Misra, K. (2006). Doing good work: Implications of performance accountability for practice in the nonprofit sector. International Journal of Rural Management, 2(2), 147-162. Available at: https://doi.org/10.1177/097300520600200202.

Blacbaud, I. (2011). Financial management of not-for-profit organizations. 2000 Daniel.

Boachie-Mensah, F. O., \& Marfo-Yiadom, E. (2005). Entrepreneurship and small business management. Accra: Ghana Universities Press.

Brealey, R. A., \& Myers, S. C. (2003). Principles of corporate finance (7th ed.). New York: McGraw-Hill/Irwin.

Carman, J. G. (2007). Evaluation practice among community-based organizations: Research into the reality. American Journal of Evaluation, 28(1), 60-75. Available at: https://doi.org/10.1177/1098214006296245.

Christine, W. L., William, P., \& Allen, G. (1999). High performance nonprofit organizations: Managing upstream for greater impact. New York: Wiley Nonprofit Series: John Wiley \& Sons, Inc.

Clark, J. (1991). Democratizing development: The role of voluntary organizations (No. E51 C593 GTZ-PR). Kumarian. Island Drive, Charleston, SC 29492 T 800.443.944

Easterly, W., \& Rebelo, S. (1993). Fiscal policy and economic growth. Journal of Monetary Economics, 32(3), 417-458

Ferreira, A., \& Otley, D. (2009). The design and use of performance management systems: An extended framework for analysis. Management Accounting Research, 20(4), 263-282. Available at: https://doi.org/10.1016/j.mar.2009.07.003.

Goodwin, J. (2003). The relationship between the audit committee and the internal audit function: Evidence from Australia and New Zealand. International Journal of Auditing, 7(3), 263-278. Available at: https://doi.org/10.1046/j.10991123.2003.00074.x.

Grischow, J. D. (2008). Rural 'community', chiefs and social capital: The case of southern Ghana. Journal of Agrarian Change, 8(1), 64-93. Available at: https://doi.org/10.1111/j.1471-0366.2007.00163.x.

Holmes, S., \& Nicholls, D. (1989). Modelling the accounting information requirements of small businesses. Accounting and Business Research, 19(74), 143-150. Available at: https://doi.org/10.1080/00014788.1989.9728844.

Jerome, M. B. (2004). Effective financial management in public and nonprofit agencies (3rd ed.). Westport, CT: Praeger.

Kareithi, R. N., \& Lund, C. (2012). Review of NGO performance research published in academic journals between 1996 and 2008. South African Journal of Science, 108(11-12), 36-44. Available at: https://doi.org/10.4102/sajs.v108i11/12.755.

Katsriku, B., \& Oquaye, M. (1996). Government and NGO relations in Ghana. Accra: Friedrich Ebert Foundation.

Kellogg, W. K. (2004). Logic model development guide. Michigan: WK Kellogg Foundation.

Kihato, C., \& Rapoo, T. (1999). An independent voice? A survey of civil society organisations in South Africa, their funding and their influence over the policy process. Johannesburg: Research Report No. 67, Centre for Policy Studies.

Lybaert, N. (1998). The information use in a SME: Its importance and some elements of influence. Small Business Economics, $10(2), 171-191$.

Mango. (2006). Management accounting for non-governmental organisations (Mango). Practical financial management for NGOs, UK.

Marc, J. E., \& Adriana, R. B. (2009). Management accounting guideline: Performance measurement of not-for-profit organizations. The Society of Management Accounting of Canada (CMA Canada) and the American Institute of Certified Public Accountants, Inc. (AICPA).

McMenamin, J. (1999). Financial management: An introduction to Tutor's guide. London: Routledg.

Mohan, G. (2002). The disappointments of civil society: The politics of NGO intervention in Northern Ghana. Political Geography, 21(1), 125-154. Available at: https://doi.org/10.1016/s0962-6298(01)00072-5.

Nayak, A., \& Greenfield, S. (1994). The use of management accounting information for managing micro businesses. Finance and the small firm (pp. 182-231). London: Routledge.

Porter, G. (2003). NGOs and poverty reduction in a globalizing world: Perspectives from Ghana. Progress in Development Studies, 3(2), 131-145. Available at: 10.1191/1464993403ps057ra.

Raymond, L., \& Magnenat-Thalmann, N. (1982). Information systems in small business: Are they used in managerial decisions? American Journal of Small Business, 6(4), 20-26. Available at: https://doi.org/10.1177/104225878200600405.

Rosen, H., \& Gayer, T. (2010). Public finance. New York: McGraw-Hill Higher Education.

Sontag-Padilla, L. M., Morganti, K. G., \& Staplefoote, L. (2012). Financial sustainability for nonprofit organizations: A review of the literature: RAND.

Speckbacher, G. (2003). The economics of performance management in nonprofit organizations. Nonprofit Management and Leadership, 13(3), 267-281. Available at: https://doi.org/10.1002/nml.15. 
Stephenson, P. (2003). Issues in back tracing events. Computer Fraud \& Security, 2003(5), 17-20. Available at: https://doi.org/10.1016/s1361-3723(03)05013-9.

Taylor, M., Heppinstall, M., Liao, M., \& Taylor, A. (2009). Performance management and funding in the third sector: A research agenda. Paper presented at the Proceedings of 16th International Annual EurOMA Conference, Göteborg, Sweden Tersine.

Teelken, C. (2008). The intricate implementation of performance measurement systems: Exploring developments in professional-service organizations in the Dutch non-profit sector. International Review of Administrative Sciences, 74(4), 615-635. Available at: https://doi.org/10.1177/0020852308098471

Theunis, K., \& Erika, B. (2011). A practical guide to the financial management of NGOs. Namibia: Namibia Institute for Democracy.

Zadek, S. (2003). From fear and loathing to social innovation. Alliance Magazine, 8(4), 2 1-24. 